\title{
Correlational Study: Internal Auditing and Management Control Environment Innovation within Public Sector in the United States
}

\author{
Karina Kasztelnik, ORCID: http://orcid.org/0000-0002-1090-3700 \\ Ph.D., MBA, CPA, CTP, Grand Canyon University, Phoenix, Arizona, USA \\ Victor W Gaines \\ DBA, MBA, CIA CGAP, CFE, Pacific Union College, Angwin, USA
}

\begin{abstract}
This article is about exploring the relationship between internal human resources auditing and environmental control in the US public sector. The main purpose of this study was to examine the extent to which the determinants of internal audit staff have the potential to influence the predictive value of the public sector control environment. The tools of the work are presented by a quantitative correlation analysis to determine the interdependence of variables (aspects of recruitment, accountability) and resultant indicator (public sector environment). By systematizing literary sources and approaches to solving the problem, as well as using the COSO 2013 Internal Control Framework as a theoretical framework, the authors focus on the question of how much internal audit recruitment, and accountability experience can influence in the foreseeable future and each of the two major COSO components. The empirical analysis was presented in the research, which made it possible to substantiate the following conclusions: the results of two multiple linear regression models did not show statistically significant except for recruitment, nonparametric correlation of Kendall's Tau-b correlation is allowed to identify significant interrelationships development. The findings of the study may be useful for implementing further transformational changes in the functioning of the global economy in the context of the growing role and importance of international audit and its positive impact on the public sector in the United States.
\end{abstract}

Keywords: Internal Auditing, Personnel Factors, Control Environment, Management, Innovation. JEI Classifications: H83, M42, M48.

Cite as: Kasztelnik, K. Gaines, V. W. (2019). Correlational Study: Internal Auditing and Management Control Environment Innovation within Public Sector in the United States. Financial Markets, Institutions and Risks, 3(4), 5-15. http://doi.org/10.21272/fmir.3(4). 5-15.2019.

(C) The Authors, 2019. This article is published with open access at Sumy State University.

\section{Introduction}

By using a quantitative correlational method, this study examines whether and to what extent aspects of internal audit personnel can predict the control environment within the public sector. Prior to this study, it was not known whether and to what extent three personnel factors of internal auditing departments - the internal audit staffing size per engagement, professional development, and the auditing experience of auditors-predict the control environment within U.S. public organizations. Research points to the importance of an internal control framework within the organization (including personnel) for the purpose of meeting operational goals (Badara \& Saidin, 2013). Without an effective internal control framework, there would be an increased chance of fraud and other illegal schemes within an organization (Noland \& Metrejean, 2013).

The significance of the study was to provide new knowledge that may be useful in improving the internal audit personnel structure and recruitment process in publicaudit agencies, with the ultimate goal of enhancing the control environment and its effectiveness. The results of the study were to benefit the governmental auditing profession as well. By examining an organization's control environment, governmental auditing agencies can effectively address the overall structure of their individual audit departments. This examination included the auditors' professional experiences, professional training, and audit team size. The overall effect would bring about increased efficiencies in conducting individual audits. These results help organizations have better audit coverage and potentially identify issues that would lead to identifying fraud, waste, and abuse and ultimately save taxpayer dollars.

\section{Literature Review}

Due to the recent corporate scandals, corporate governance has become critical to an organization's operations. Suyono and Hariyanto's (2012) case study examined the positive relationship between corporate governance, organization commitment, internal audit, and internal control in local government organizations in Indonesia. In 
Financial Markets, Institutions and Risks, Volume 3, Issue 4, 2019

ISSN (online) - 2521-1242 ISSN (print) - 2521-1250

recent years, internal auditing has been increasingly critical to organizations as a mechanism for monitoring corporate governance, risk management, and internal control. Therefore, many organizations set up an internal audit department to provide organizational oversight of their internal control system. Internal audit departments also assist organizations by providing recommendations to improve these systems so that these organizations can meet their operational goals.

In providing assistance and oversight, internal audit departments have needed to use a systematic, disciplined approach to performing their assessment in evaluating an organization's internal control structure (The Institute of Internal Auditors, 2013). The Committee of Sponsoring Organizations of the Treadway Commission (COSO) has provided guidance in accounting and auditing. In 1992, COSO developed the Internal Control-Integrated Framework, which provides a systematic approach for assessing internal control. In 2013, COSO updated the Internal Control-Integrated Framework to meet the needs of modern business (Committee of Sponsoring Organizations of the Treadway Commission, 2013).

This study provided new knowledge that may be useful in improving the internal audit personnel structure and recruitment process in audit agencies, with the ultimate goal of enhancing the control environment and its effectiveness. This study also has far-reaching implications in governmental auditing. By emphasizing an organization's control environment, the internal auditors can identify potential issues that are systemic to the organization's organizational behavior. By addressing issues such as "tone at the top" (management's commitment to integrity) and the organization's ethical environment within the organization, the auditors may gain important insight into potential negative ramifications of the organization as it pertains to fraud, waste, and abuse. Increased scrutiny of an organization's control environment may result in the organization operating more efficiently and effectively, thus saving taxpayer dollars.

Additionally, this study has far-reaching implementations, whereas, an effective and efficient internal audit department can increase the likelihood of identifying deficiencies and focus on the importance of good governance and the aspect of the internal audit industry. As an important part of an organization's governance system and internal audit department, an internal audit department can positively reflect on attributes and the behavioral tones of an organization's control environment. Thus, this study can emphasize the importance of the internal audit department as a whole and its effectiveness.

Additionally, this study has implementations for the global auditing world. Because audit departments spend a significant amount of time in the planning stage of an audit, this study can assist chief audit executives in effectively planning their required staff, professional development, and the auditing experience of auditors based upon risk. This would, in turn, assist audit departments in improving their effectiveness.

\section{Governance}

In the aftermath of the most recent corporate scandals and global financial crises, the idea of corporate governance has recently come to the attention of regulators and the public. This increased regulation denotes the requirements of corporations to be aware of corporate governance (Dominic \& Martinov-Bennie, 2011). With the implementation of Sarbanes-Oxley Act of 2002 section 404, there has been an increasing demand for corporate governance. In section 404 of the Sarbanes-Oxley Act, organizations must report on their overall internal control system (Schelker, 2013). This increased demand for corporate governance has also brought the internal audit function and risk management into the limelight. Presently, for an organization to be on the New York Stock Exchange, the organization must have an internal audit department and an audit committee (Birkett, 2014). For the internal audit function to perform any reviews on an organization's internal control system, there is a need for a framework to ensure that these controls are working as intended. Within this framework are the concepts of internal control. It is up to the internal audit function to perform systematic reviews that include the components of internal control within an organization's internal control system and corporate governance.

According to Balc, Ilies, Cioban, and Cuza (2013), over the past 2 decades, there were several different definitions of the concept of corporate governance. Guxholli, Karapici, and Gjinopulli (2012) defined corporate governance as a system that directs and controls the organization. Balc et al. (2013) suggested that the definition established by the Organization for Economic Cooperation and Development (OECD) is the best approach. This definition stated that corporate governance was the distribution of rights and responsibilities among different categories within the organization. Such categories included the board of directors, managers, stockholders, and other categories. The authors concluded that corporate governance mainly focuses on a 
Financial Markets, Institutions and Risks, Volume 3, Issue 4, 2019

ISSN (online) - 2521-1242 ISSN (print) - 2521-1250

balancing act between forces both inside and outside of the organization (Balc et al., 2013). Timea (2011) shared this viewpoint.

This commitment toward governance has increased exponentially since the aftermath of Sarbanes-Oxley. The accounting and auditing fields have collaborated to examine practical methods to implement, refine, and improve internal control. Due to this collaboration, the accounting and auditing fields turned to the Sponsoring Organizations of the Treadway Commission (COSO) for a theoretical framework. This theoretical framework would help both industries in evaluating internal control (Janvrin, Payne, Byrnes, Schneider, \& Curtis, 2012). Thus, in 1992, the Sponsoring Organizations of the Treadway Commission developed the COSO Internal Control-Integrated Framework to help organizations to improve their control structure.

\section{Internal Control-Integrated Frameworks}

According to Kapić (2013), to design an integrated control system, one must start with internal control. The author defined internal control as the methods and procedures embedded in the organization by management to ensure the smooth running of operations. Internal control is a process, not a means or an end in itself. Thus, an organization must constantly review its internal controls to ensure that they are operating correctly. There is a direct relationship between the objectives of internal control and the organization's efficiency and effectiveness along with achieving the organization's goals. Kapić (2013) added that internal control is a system that helps to provide reasonable assurance of the organization's objectives. These objectives include the following: (a) reliability of the financial statements, (b) compliance with laws and regulations, (c) effectiveness and efficiency of business operations, and (d) safeguard of assets. The effectiveness and efficiency of the organization's operations are most significant as it pertains to the daily operations of an organization. Thus, the system of internal control enables management to achieve its operational and business objectives at all levels of the organization.

Whereas an organization's particular industry may dictate what framework they use, the most widely used and researched internal control framework was developed by COSO. Formed in 1985, COSO consists of five sponsoring organizations: the American Accounting Association, the AICPA, the Financial Executives International, the Institute of Internal Auditors, and the Institute of Management Accountants. These groups represented over a half million members including many outside the United States (Tidrick, 2012). Each of these organizations represents a vast wealth of knowledge within the accounting and auditing industry. Together, these organizations developed one of the first comprehensive and widely used integrated frameworks on internal control.

Developed in 1992, the COSO Internal Control-Integrated Framework provided the initial universal definition of internal control. Additionally, the framework was a theoretical basis for internal control that can be used by internal auditors to evaluate the organization's internal control system (Wilson, Wells, Little, \& Ross, 2014). This theoretical basis identified the five components of internal control: (1) control environment, (2) risk assessment, (3) control activities, (4) information and communication, and (5) monitoring activities (Wilson et al., 2014).

The initial framework was intended to assist organizations in managing and developing the systems of internal control by using the insights from academia and industry. This framework was adaptable to the changing world of industry (Janvrin et al., 2012). However, in 2013 the Committee of Sponsoring Organizations of the Treadway Commission revised the 1992 COSO Internal Control-Integrated Framework to include 17 principles. The addition of these principles represents the most significant change to the Framework since its inception. The purpose of these principles was to provide clarity regarding the role, implementation, and behavior of the internal control as well as assessing their effectiveness (Burns \& Simer, 2013; D'Aquila, 2013; see Table 2). These principles are broad in concept so that they may apply to a wide variety of organizations. This area would include those governmental and not-for-profit organizations (D'Aquila \& Houmes, 2014). According to D'Aquila and Houmes, this framework was reviewed by the Government Accountability Office for the purpose of revising the outdated Standards for Internal Control in the Federal Government. This new version of the governmental standards incorporated key concepts within the framework.

A weak control environment within an organization could be detrimental to its existence. According to Badara and Saidin (2013), governments should improve the effectiveness of their internal control system for the purpose of providing and improving good governance. The literature revealed the scarcity of studies on the relationship between an organization's control environment and the internal audit function. Badara and Saidin (2013) pointed to the need for empirical research in the area of organizations' control environment and its 
Financial Markets, Institutions and Risks, Volume 3, Issue 4, 2019

ISSN (online) - 2521-1242 ISSN (print) - 2521-1250

relationship with the internal audit function. To address this gap in the research, the current study investigated the impact of three personnel factors of internal auditing departments - the internal audit staffing size per engagement, professional development, and the auditing experience of auditors - on the control environment within U.S. organizations.

\section{Control Environment}

A review of the literature surrounding the control environment component of COSO mainly focuses on the definition of the component and the five principles associated with the component. Additionally, in some case studies, authors discuss the circumstances surrounding organizations that had a weak control environment and their results. These studies emphasize the importance of having a strong control environment within their organization. Finally, in a few cases, the authors address the control environment within the government. These cases are extremely broad in concept and are limited as they attempt to address the influence the control environment has within an internal audit function.

According to the Committee of Sponsoring Organizations of the Treadway Commission (2013), the control environment is a set of standards, processes, and structures that provide the basis for an organization's corporate governance. It also offers a basis for administrating internal control throughout the organization. It is up to the board of directors and senior management to establish the tone of the organization to ensure that internal control is a priority. According to Janvrin et al. (2012), the elements of an organization's control environment is their integrity and ethical values along with management's philosophy and operating style. These concepts set the tone for the entire organization to include the internal audit function. According to Spoehr's (2012), the tone at the top requires the organization to have explicit and implicit policies that align with the organization's goals and objectives. Thus, although it is important for the organization to review its policies, procedures, and code of conduct, it is equally important for the organization to understand its internal culture and actions. Both of these are an essential part of an organization's control environment. Even so, according to Badara and Saidin (2013), there is a need for research on how an organization's control environment relates to the effectiveness of internal audit function at the local government level.

\section{Research Questions and Hypotheses}

Using the same methodology used by Sarens and Abdolmohammadi (2011) research that examining the relationship between organizations control environment and the size of the internal audit function, we examined whether and to what extent aspects of internal audit personnel —staffing size per engagement, professional development, and the auditing experience of auditors - can predict the control environment within the public sector. The criterion variables were two control environment components as listed:

Recruitment: The organization demonstrates a commitment to attract, develop, and retain competent individuals in alignment with objectives.

Accountability: The organization holds individuals accountable for their internal control responsibilities in the pursuit of objectives.

Using two multi-linear regression models, we hypothesize the following:

H1: The internal audit staffing size per engagement, professional development, and the auditing experience of auditors are statistically significant predictors of the implementation of recruitment, within the public sector.

H2: The internal audit staffing size per engagement, professional development, and the auditing experience of auditors are statistically significant predictors of the implementation of accountability, within the public sector.

While other research studies analyzed different aspects of COSO, Badara and Saidin (2013) examined the impact and effectiveness internal controls have on the public level. They concluded that there was a need for further empirical research on the relationship between an organization's control environment and its particular internal audit function. For this examination, we were able to derive the following research question.

RQ1: To what extent does the internal audit staffing size per engagement, professional development, and the auditing experience of auditors predict the recruitment and accountability within the control environment within U.S. organizations? 


\section{Research Design}

To collect the necessary data, we used an electronic online survey instrument. The target population for the study comprised of two public auditing organizations in the United States using a convenience sample method. All participants in the study were anonymous.

\section{Description of the Research Design}

A causal-comparative design was not appropriate because that approach involves comparison of groups defined by one or more categorical independent variables in terms of features defined by the criterion variables. This study involved no comparison of groups. The researcher examined relationships among continuous predictor and criterion variables. The researcher's choice for a nonexperimental correlational aligned with the study purpose, which was to investigate relationships between predictor and criterion variables. Earlier studies in the area of control environment research conducted by Sarens and Abdolmohammadi (2011), Octavia (2013), and Schmidt (2014) used nonexperimental correlational designs for the purpose of examining relationships among variables. Thus, a nonexperimental correlational research design was considered the most appropriate design for this study.

\section{Sampling Procedures}

To collect quantitative data, we administered an online survey to a convenience sample of public auditors. The target population for this recruitment consisted of two auditing departments: the Naval Audit Service, and the Marine Corps Nonappropriated Fund Audit Service. Both of these departments represent governmental auditing agency within the United States use the United States Government Auditing Standards (U.S. Government Accountability Office, 2014). After data collection, the researcher performed an initial examination of the data set to detect missing data and outliers. All incomplete cases and cases with incorrect data were discarded from the dataset. Then the researcher computed the composite variables as means of the items corresponding to each scale or subscale, and performed a reliability analysis for all composite measures.

The next step involved the computation of descriptive statistics for the sample profile and the variables of interest in this study. For the continuous variables, the researcher computed the following descriptive statistics: mean, standard deviation, minimum, maximum, skewness, and kurtosis. The last two statistics were used to assess the normality of the distribution curve relative to the normal bell curve.

Prior to taking the survey, participants received adequate information on the purpose of the study and acknowledgment that they may remove themselves from the study at any time. Justice focused on the fairness in the dissemination of the results. As it pertains to this study, the researcher disseminated the results of this study to all parties participating in the study to ensure equal benefit.

The fair treatment of each participant regardless of background and state of mind was paramount. Each participant had the opportunity to express himself or herself. This study did not anticipate any ethical problems. Thus, the protections outlined in the study ensured the protection of the human subjects in this research.

\section{Data Analysis and Test of Assumptions}

Participants did not experience any enhancement, pressure, or persuasion before or during the study. There was no pressure or coercion in response to the study. The researcher informed each participant of the benefits and purpose of the study. This study was nonexperimental; thus, debriefing sessions with participants was unnecessary. Due to the coding of the participants, the risk of participant identification was minimal. The results of the study were not fabricated or suppressed, and were formulated to satisfy the purpose of the study. This study did not use words that were biased in nature.

Finally, this researcher observed the three basic principles of the Belmont Report (1979): (a) respect for persons, (b) beneficence, and (c) justice. Both the respect for persons and justice were relevant to the study. According to the Belmont Report, respect for persons incorporates the treatment of the individual as an anonymous agent. Additionally, the participant's diminished autonomy entitles protection. In this study, to ensure this protection, the participation of the respondents was voluntary. Prior to taking the survey, participants received adequate information on the purpose of the study and acknowledgment that they may remove themselves from the study at any time. Justice focused on the fairness in the dissemination of the results. As it pertains to this study, the researcher disseminated the results of this study to all parties participating in the study to ensure equal benefit. 
Financial Markets, Institutions and Risks, Volume 3, Issue 4, 2019

ISSN (online) - 2521-1242 ISSN (print) - 2521-1250

The fair treatment of each participant regardless of background and state of mind was paramount. Each participant had the opportunity to express himself or herself. This study did not anticipate any ethical problems. Thus, the protections outlined in the study ensured the protection of the human subjects in this research.

Although one may view this as a major limitation of this particular study, the survey results are valid and reliable based on the following reasons. First, the sample size composed of 21 participants from one public agency. This represents a $75.6 \%$ response rate. Such a response rate reduces the risk of the sample size not representing the population. Additionally, the organization that did participate must follow the same guidelines of other government organizations as it pertains to control environment. Secondly, of the 21 participants, 18 (86\%) participants were audit managers or above. The participants' distribution by job description was as follows: one chief audit executive, seven audit directors, ten audit managers, and three staff auditors participated in taking the electronic survey (Table 1). This high-level management participation in the study only adds validity to the results. Lastly, the average years of experience of those participated were 19.9 years. Additionally, the average amount of formalized training for the year was 48.62 hours per year (Table 2). Thus, one may conclude that the survey respondents were season auditors and had vast experience in the area of internal auditing and internal control.

Table 1. Distribution of Participants by Job Description

\begin{tabular}{|l|r|r|}
\hline \multicolumn{1}{|c|}{ Job Description } & $n$ & $\%$ \\
\hline Chief audit executive, or equivalent & 1 & 4.8 \\
\hline Director or senior manager & 7 & 33.3 \\
\hline Manager & 10 & 47.6 \\
\hline Staff & 3 & 14.3 \\
\hline Total & 21 & 100.0 \\
\hline
\end{tabular}

Source: Compiled by Author.

Table 2. Participant Experience and Training

\begin{tabular}{|l|c|c|c|}
\hline \multicolumn{1}{|c|}{ Description } & Minimum & Maximum & $M$ \\
\hline Years of professional experience & 6 & 33 & 19.9 \\
\hline Hours of formalized training (yearly) & 25 & 120 & 48.62 \\
\hline
\end{tabular}

Source: Compiled by Author.

Prior to performing this descriptive statistical analysis, we performed a Cronbach's alpha analysis to determine how closely the two control environment principles and overall control environment relate to the three subscales variables and each other. Based upon the results of this analysis, the two internal control principles did relate closely to the three subscales variables and each other with scores well above 0.7 (Table 3 ) in the. Thus, the results are reliable.

Table 3. Reliability Analysis for the Criterion Scale and Subscales

\begin{tabular}{|l|c|c|}
\hline Description & Cronbach's Alpha & Number of Items \\
\hline Recruitment & .718 & 3 \\
\hline Accountability & .860 & 3 \\
\hline
\end{tabular}

Source: Compiled by Author.

Table 4 and 5 showed the results of the descriptive statistics computed for both the criterion and predictor variables. The mean scores of the two principals were above 3 (moderate influential). The consistency of the negative skew statistics indicated that all the distributions were platykurtic. However, the values were within the normal range. Two of the kurtosis values were outside the normal \pm 1 range - recruitment, and the overall control environment - indicating small and moderate violations of normal bell curve distribution for these two criteria.

Table 4. Descriptive Statistics for the Criterion Variables

\begin{tabular}{|l|c|c|c|c|c|c|c|}
\hline & $M$ & Mdn & SD & Min & Max & Skewness & Kurtosis \\
\hline Recruitment & 3.49 & 3.66 & .81 & 2 & 5 & -.622 & 1.165 \\
\hline Accountability & 3.49 & 3.66 & .82 & 1 & 4 & -.302 & -.386 \\
\hline
\end{tabular}

Note. $\mathrm{N}=21$.

Source: Compiled by Author. 
Table 5. Descriptive Statistics for the Predictor Variables

\begin{tabular}{|c|c|c|c|c|c|c|}
\hline & $M$ & $S D$ & Min & $\operatorname{Max}$ & Skewness & Kurtosis \\
\hline Staffing Size & 10.07 & 9.003 & 3 & 33 & 1.922 & 2.817 \\
\hline Professional Development & 48.62 & 19.737 & 25 & 120 & 2.709 & 8.661 \\
\hline Experience & 19.9 & 7.085 & 6 & 33 & -.216 & .059 \\
\hline
\end{tabular}

Note. $N=21$.

Source: Compiled by Author.

Table 5 identified that the shape of the distribution for the predictor variables was positively skewed, with except for auditing experience. Professional development showed kurtosis was higher than 3 , meaning that the distribution was leptokurtic. The large kurtosis value suggested that the distribution was normal, which represents a limitation to this analysis. This result may be due to the smallness of the sample size.

Before conducting the planned multiple linear regression analysis, we performed a check of the assumptions. The first two assumptions, continuous criterion variable, and two or more predictor variables were satisfied because the criterion variable was continuous and there were more than two predictor variables. To check for the independence of observation, we performed a Durbin-Watson test on the predictor variables. The results of the Durbin-Watson values ranged between 1.255 and 2.051. Thus, the researcher concluded that the assumption of independence of residuals was satisfied (Table 6).

Table 6. Results of the Test of Independence of Observations

\begin{tabular}{|c|c|}
\hline \multicolumn{1}{|c|}{ Criterion Variable } & $\begin{array}{c}\text { Durbin-Watson } \\
\text { Average Score (1-5) }\end{array}$ \\
\hline Principle 4 Recruitment & 2.051 \\
\hline Principle 5 Accountability & 1.255 \\
\hline
\end{tabular}

Source: Compiled by Author.

In assessing the multicollinearity, we performed a variance inflation factor (VIF). The results of this analysis showed all three predictor variables were below 10. Thus, one can conclude there was no problem with collinearity in this particular data set (Table 7).

Table 7. Results of the Multicollinearity Analysis for the Predictor Variables

\begin{tabular}{|l|c|c|}
\hline \multicolumn{1}{|c|}{ Model } & \multicolumn{2}{c|}{ Collinearity Statistics } \\
\cline { 2 - 3 } & \multicolumn{2}{c|}{ VIF } \\
\hline (Constant) & & 1.023 \\
\hline Professional Development & .978 & 1.038 \\
\hline Experience & .964 & 1.018 \\
\hline Staffing Size & .982 & \\
\hline
\end{tabular}

Note. $\mathrm{N}=21$. Tolerance is defined as $\mathrm{T}=1-\mathrm{R}^{2}$. Variance Inflation Factor $(\mathrm{VIF})$ is defined as VIF $=1 / \mathrm{T}$.

Source: Compiled by Author.

The analysis conducted to find answers to the six research questions included six multiple linear regression models. The researcher used the stepwise method of entering the predictors into the regression equation. This approach automatically ranked the predictors in terms of the strength of their impact on each criterion. All models had the same set of three predictors (internal audit staffing size per engagement, professional development, and the auditing experience of auditors), but each model had a different criterion (the control environment overall scale and each one of the five subscales: integrity, independent oversight, providing structure, recruitment, and accountability). The results included information about the incremental variance accounted for by each statistically significant predictor. The findings from each model were used to answer the corresponding research questions.

\section{Results}

\section{Test of Hypotheses}

\section{Recruitment (H1)}

The results of the study showed that the internal audit staffing size per engagement, professional development, and the auditing experience of auditors as a whole are not statistically significant predictors of the implementation of recruitment within the public sector. As identified in Table 8, the results of the multiple linear regression analysis demonstrate that the three predictor variables (internal audit staffing size per engagement, professional development, and the auditing experience of auditors) explained $24.8 \%$ of the variance in recruitment, R2 $=0.248$, Adjusted R2 $=0.116, \mathrm{~F}(3,17)=1.871, \mathrm{p}>0.05$ (Table 9). The 
Financial Markets, Institutions and Risks, Volume 3, Issue 4, 2019

ISSN (online) - 2521-1242 ISSN (print) - 2521-1250

standardized Beta coefficients for this model, indicating the percentage of one standardized unit change in the criterion variable associated with the standardized unit change in each predictor, were not statistically significant except for professional training which had a significance level of .046 (Table 9). However, the internal audit staffing size per engagement, professional development, and the auditing experience of auditors are not statistically significant predictors of the implementation of recruitment, within the public sector as a whole. Based on the results, we concluded that audit staffing size, professional development, and audit experience were not statistically significant predictors of recruitment.

\section{Accountability (H2)}

The results of the study showed that the internal audit staffing size per engagement, professional development, and the auditing experience of auditors as a whole are not statistically significant predictors of the implementation of accountability within the public sector. As identified in Table 10, the results of the multiple linear regression analysis demonstrate that the three predictor variables (internal audit staffing size per engagement, professional development, and the auditing experience of auditors) explained $2 \%$ of the variance in accountability, R2 $=0.020$, Adjusted R2 $=-0.153, \mathrm{~F}(3,17)=0.113, \mathrm{p}>0.05$ (Table 8). According to Janvrin et al. (2012), the elements of an organization's control environment are their integrity and ethical values, along with management's philosophy and operating style. These concepts set the tone of the organization and their perception of the internal audit department. Noland and Metrejean (2013) spoke about an expense fraud committed at the Blue Grass Airport due to the lack of ethical values held by the executives, and a lack of oversight by the airport's board. Without any review process, potential wrongdoing by the executives was undetected. This fraud case shows the importance of integrity and ethical values as it pertains to an organization's control environment (Noland \& Metrejean, 2013). However, the findings from the study were inconsistent with the previously reviewed literature and suggested that the three predictor variables did not influence Principle 1, integrity, of COSO. Nevertheless, based on the descriptive statistics data, the mean score of Principle 1, integrity, did show evidence of being moderately influential within U.S. public organizations. Thus, there is a possibility of other predictor variables that could potentially influence Principle 1.

The standardized Beta coefficients for this model, indicating the percentage of one standardized unit change in the criterion variable associated with the standardized unit change in each predictor, were not statistically significant (Table 9). According to Badara and Saidin (2013), an organization's control environment assists in reducing the levels of fraud activity within an organization. Thus, an effective control environment within the public sector is extremely important for the effectiveness of its operations. Sarens and Abdolmohammadi (2011) identified a positive correlation between an organization's control environment and the relative size of the internal audit function. Additionally, in the literature review, the authors identified a correlation between corporate governance and the internal audit function. When organizations invest in an internal audit department, they are also investing in their corporate governance. Lack of investment in internal audit departments could be a potential leading indicator of fraud or waste and abuse (Noland \& Metrejean, 2013; Rittenberq, 2013). However, the findings from the study are inconsistent with the previously reviewed literature and suggest that the three predictor variables did not influence the five principles of COSO. Nevertheless, based on the descriptive statistics data, the mean scores of all five principles showed that an organization's overall control environment is moderately influential within U.S. public organizations. Thus, there is a possibility of other predictor variables that could potentially influence the five principles of COSO. Based on the results of the planned multiple linear regression analysis, we concluded that audit staffing size, professional development, and audit experience were not statistically significant predictors of accountability.

Table 8. Hypotheses Summaries

\begin{tabular}{|c|c|c|c|c|c|c|c|c|c|c|}
\hline \multirow[b]{2}{*}{ Model } & \multirow[b]{2}{*}{$R$} & \multirow[b]{2}{*}{$R$ Square } & \multirow[b]{2}{*}{$\begin{array}{l}\text { Adjusted } \\
R \text { Square }\end{array}$} & \multirow[b]{2}{*}{$\begin{array}{l}\text { Std. Error of } \\
\text { the Estimate }\end{array}$} & \multicolumn{5}{|c|}{ Changes Statistics } & \multirow[b]{2}{*}{$\begin{array}{l}\text { Durbin- } \\
\text { Watson }\end{array}$} \\
\hline & & & & & $\begin{array}{l}R \text { Square } \\
\text { Change }\end{array}$ & $F$ Change & $d f 1$ & $d f 2$ & $\begin{array}{c}\text { Sig. } F \\
\text { Change }\end{array}$ & \\
\hline 1 & 0.498 & .248 & 0.116 & 0.759 & 0.248 & 1.871 & 3 & 17 & 0.173 & 2.051 \\
\hline 2 & 0.140 & 0.020 & -0.153 & 0.881 & 0.020 & 0.113 & 3 & 17 & 0.951 & 1.255 \\
\hline
\end{tabular}

Source: Compiled by Author.

Table 9. Coefficients Analysis

\begin{tabular}{|c|c|c|c|c|c|c|c|c|c|c|c|c|c|}
\hline \multirow[b]{2}{*}{ Model } & & \multirow{2}{*}{$B$} & \multirow{2}{*}{$\begin{array}{l}\text { Std. } \\
\text { Error }\end{array}$} & \multirow{2}{*}{$\begin{array}{l}\text { Std. } \\
\text { Beta }\end{array}$} & \multirow{2}{*}{$t$} & \multirow{2}{*}{ Sig. } & \multicolumn{2}{|c|}{$\begin{array}{c}95 \% \text { Confidence } \\
\text { level at } B\end{array}$} & \multicolumn{3}{|c|}{ Correlation } & \multicolumn{2}{|c|}{$\begin{array}{c}\text { Collinearity } \\
\text { Statistics }\end{array}$} \\
\hline & & & & & & & $\begin{array}{l}\text { Lower } \\
\text { Bound }\end{array}$ & $\begin{array}{l}\text { Upper } \\
\text { Bound }\end{array}$ & $\begin{array}{l}\text { Zero- } \\
\text { order }\end{array}$ & Partial & Part & Tolerance & $V I F$ \\
\hline & (Constant) & 1.876 & .742 & & 2.530 & .022 & .312 & 3.441 & & & & & \\
\hline & Experience & .029 & .024 & .259 & 1.217 & .240 & -.022 & .081 & .198 & .283 & .256 & .978 & 1.023 \\
\hline
\end{tabular}


Table 9 (cont.). Coefficients Analysis

\begin{tabular}{|c|l|c|c|c|c|c|c|c|c|c|c|c|c|}
\hline 1 & $\begin{array}{l}\text { Professional } \\
\text { Develop. }\end{array}$ & .019 & .009 & .460 & 2.148 & .046 & .000 & .037 & .406 & .462 & .452 & .964 & 1.038 \\
\hline & Staff Size & .011 & .019 & .127 & .599 & .557 & -.029 & .052 & .081 & .144 & .126 & .982 & 1.018 \\
\hline & Constant) & 3.585 & .861 & & 4.163 & .001 & 1.768 & 5.402 & & & & & \\
\hline & Experience & -.013 & .028 & -.113 & -.463 & .649 & -.072 & .046 & -.118 & -.112 & -.111 & .978 & 1.023 \\
\hline 2 & $\begin{array}{l}\text { Professional } \\
\text { Develop. }\end{array}$ & .002 & .010 & .056 & .228 & .822 &.-.019 & .024 & .065 & .055 & .055 & .964 & 1.038 \\
\hline & Staff Size & .005 & .022 & .059 & .242 & .811 & -.041 & .052 & .046 & .059 & .058 & .982 & 1.018 \\
\hline
\end{tabular}

Source: Compiled by Author.

\section{Additional Analyses}

\section{Substantive Testwork}

Due to the low power in the multiple linear regression analysis, the assumption violations, and the absence of any statistical significance small to large effects, thus making the above findings inconclusive, we performed an alternative analysis using the nonparametric Kendall's tau-b correlations (Table 10). The results of this alternative analysis revealed a statistically significant positive correlation between professional development and recruitment, $\tau \mathrm{b}=0.388, \mathrm{p}=0.030$. This corroborates with the results identifies with Recruitment (H1) testing.

Table 10. Kendall's Tau-b Correlation Analysis

\begin{tabular}{|l|c|c|c|c|}
\hline & & Experience & $\begin{array}{c}\text { Professional } \\
\text { Development }\end{array}$ & Staffing Size \\
\hline Recruitment (H4) & Correl. Coefficient & .197 & $.388^{*}$ & -.062 \\
\hline & Sig. (2-Tailed) & .241 & .030 & .711 \\
\hline Accountability (H5) & $N$ & 21 & 21 & 21 \\
\hline & Correl. Coefficient & -.083 & -.156 & -.052 \\
\hline & Sig. (2-Tailed) & .621 & .385 & .757 \\
\hline
\end{tabular}

Note. * Correlation is significant at the 0.05 level (2-tailed).

Source: Compiled by Author.

\section{Discussion}

\section{Theoretical and Practical Implications}

The purpose of this quantitative correlational study was to examine whether and to what extent three aspects of internal audit personnel - the internal audit staffing size per engagement, professional development, and the auditing experience of auditors - impact the overall control environment and its five components - integrity, independent oversight, providing structure, recruitment, and accountability - within public organizations in the United States. Broadly defined, control environment focused on integrity, ethical values, management's philosophy, and the operating style of the organization. Because of the importance the control environment had in an organization's internal control system and corporate governance, this study used the 2013 COSO Internal Control-Integrated Framework as a theoretical framework. Critical to any organization's internal control framework are the standards, procedures, and structures that provide a basis for the organization's internal control structure. Theoretically, for an organization to have a sound internal control framework, an effective control environment must be in place (Noland \& Metrejean, 2013). In practice, organizations have overlooked their control environment because it was difficult to test and verify. This lack of review was found in most organizations, whether profit, not-for-profit public, or governmental. Thus, the practical significance of the study was that the expected new knowledge might be used to improve the internal audit personnel structure and recruitment process in audit agencies, with the ultimate goal of enhancing the control environment and its effectiveness.

\section{Conclusions}

Thus, future research would be needed in this area to validate the magnitude of this relationship in the hopes to be able to shine the light on how potential development may impact recruitment in the area of an organization's control environment. The researcher could not randomly select participants. Therefore, the researcher used convenience sampling, which has an inherent risk that the sample may not be representative of the population. This limitation undermines the internal and external validity of results and the researcher's ability to generalize the findings from the sample to the population. 
Financial Markets, Institutions and Risks, Volume 3, Issue 4, 2019

ISSN (online) - 2521-1242 ISSN (print) - 2521-1250

Although the importance of an organization's control environment is essential in the corporate world, the literature suggested the need for research surrounding the control environment as it relates to the internal audit function within audit departments. Badara and Saidin (2013) suggested that an effective internal control system or control environment within the government sector could influence the effectiveness of the internal audit department. However, the authors stated that this concept needed to be validated empirically. The focus of this study was to examine whether and to what extent three aspects of internal audit personnel - the internal audit staffing size per engagement, professional development, and the auditing experience of auditors - predict the control environment within U.S. organizations. This study included two research questions that guided the research regarding the relationships between the two criterion variables and the three predictor variables (the internal audit staffing size per engagement, professional development, and the auditing experience of auditors).

Research Question 1: Recruitment. The results of the study showed that the internal audit staffing size per engagement, professional development, and the auditing experience of auditors are not statistically significant predictors of the implementation of recruitment, within U.S. organizations, $\mathrm{R} 2=0.248$, Adjusted R2 $=0.116$, $\mathrm{F}(3,17)=1.871, \mathrm{p}>0.05$. While there seemed to be a correlation between professional development and recruitment, based on the overall results findings, the researcher accepted the null hypothesis stated for the first research question.

Research Question 2: Accountability. The results of the study show that the internal audit staffing size per engagement, professional development, and the auditing experience of auditors are not statistically significant predictors of the implementation of accountability within U.S. organizations, R2 $=0.020$, Adjusted R2 $=$ $0.153, \mathrm{~F}(3,17)=0.113, \mathrm{p}>0.05$. Based these findings, the researcher accepted the null hypothesis stated for the second research question.

\section{Recommendation for the Future Study}

As it pertains to recommendations for future practices, one must understand the importance of internal control as it relates to an organization's control environment. As a result, this research study identified a positive correlation between professional development and Principle 4, recruitment, which was also identified as statistically significant using the nonparametric Kendall's tau-b correlation analysis. Although these results could be helpful to the chief audit executive in professional development planning, future research would be needed to validate these results with a larger population and sample size. Additionally, this research did identify the importance with which government auditors view an organization's control environment. These results coincide with the previous research completed in the corporate arena. This knowledge brings to light the exponential importance of an organization's control environment. Therefore, audit directors must be aware of this influential principle of an organization's internal control on their overall engagement. Furthermore, an effective evaluation of the organization's control environment could affect the way audit departments perform their audits.

\section{References}

1. Badara, \& Saidin. (2013). Impact of the effective internal control system on the internal audit effectiveness at local government level. Journal of Social and Development Sciences, 4(1), 16-23.

2. Balc, L. B., Ilies, R., Cioban, B., \& Cuza, B. (2013). Corporate governance: Conceptual approaches. Managerial Challenges of the Contemporary Society, 5, 14-17.

3. Birkett, B. S. (2014). The recent history of corporate audit committees. Accounting Historians Journal, 13(2), 109-124.

4. Burns, J., \& Simer, B. (2013). COSO Enhances its Internal Control: Integrated framework. DeloitteHeADS Up, 20(17), 1-16.

5. Cohen, J. (1992). A Power Primer. Psychological Bulletin, 112(1), 155-159.

6. Committee of Sponsoring Organizations of the Treadway Commission. (2013). Internal Control -Integrated Framework. Internal Control over external financial overreporting: A compendium of approaches in examples: New York, NY.

7. D’Aquila, J. (2013). COSO's Internal Control: Integrated Framework. CPA Journal, 83(10), 22-29.

8. D’Aquila, J., \& Houmes, R. (2014). COSO`s Updated Internal Control and Risk Management Frameworks. CPA Journal, 84(5), 54-59.

9. Dominic, S. B. S., \& Martinov-Bennie, N. (2011). The internal audit function. Managerial Auditing Journal, 26(7), 605-622. doi:10.1108/02686901111151332

10. Guxholli, S., Karapici, V., \& Gjinopulli, A. (2012). Corporate governance and audit. China-USA Business 
Review, 11(2) 253-267.

11. Janvrin, D. J., Payne, E. A., Byrnes, P., Schneider, G. P., \& Curtis, M. B. (2012). The updated COSO Internal Control --Integrated Framework: Recommendations and opportunities for further research. Journal of Information Systems, 26(2), 189-213. doi:10.2308/isys-50255

12. Kapić, J. (2013). Internal supervision, internal control and internal audit. Business Consultant/Poslovni Konsultant, 5(31), 62-73.

13. Laerd Statistics. (2013). Multiple Regression Analysis using SPSS Statistics: Retrieved from https://statistics.laerd.com/spss-tutorials/multiple-regression-using-spss-statistics.php.

14. Noland, T. G., \& Metrejean, E. (2013). The importance of the control environment: Expense account fraud at blue grass airport. Journal of Business \& Economics Research (Online), 11(2), 97.

15. Sarens, G., \& Abdolmohammadi, M. J. (2011). Monitoring effects of the internal audit function: Agency theory versus other explanatory variables. International Journal of Auditing, 15(1), 1-20. doi:10.1111/j.1099-1123.2010.00419.x

16. Schelker, M. (2013). Auditors and corporate governance: Evidence from the public sector. Kyklos, 66(2), 275-300. doi:10.1111/kykl.12021

17. Spoehr, W. D. (2012). Consequences of this connects of "tone at the top" at the institutional and operational level. Financial Executive, 28(10), 68-69.

18. Suyono, E., \& Hariyanto, E. (2012). Relationship between internal control, internal audit, and organization commitment with good governance: Indonesian case. China - USA Business Review, 11(9).

19. The Institute of Internal Auditors. (2013). International Professional Practices Framework (IPPF). Retrieved from www.theiia.org.

20. The IIA Research Foundation. (2015). 2015 Global internal audit common body of knowledge (CBOK) practitioner study. Retrieved from https://na.theiia.org/iiarf/Pages/Common-Body-of-KnowledgeCBOK.aspx:

21. Tidrick, D. E. (2012). Improving governance and internal control. The CPA Journal, 82(10), 6-11.

22. Timea, F. M. (2011). Corporate governance: The rolling application of the principle of transparency. Annals of the University of Oradea, Economic Science Series, 20(1), 616-621.

23. Wilson, T., Wells, S., Little, H., \& Ross, M. (2014). A history of internal control: From then to now. Academy of Business Journal, 1, 73-89. 